\title{
MECHANISMS OF B LYMPHOCYTE INVOLVEMENT IN THE PATHOGENESIS OF MULTIPLE SCLEROSIS
}

\author{
Melnikov MV ${ }^{1,2,3 凶}$, Rogovskii VS ${ }^{1,2}$, Lopatina $A V^{1,2}$, Sviridova $A A^{1,2}$, Volkov $A I^{1}$, Boyko $A N^{1,2}$ \\ ${ }^{1}$ Federal Center for Brain and Neurotechnology of Federal Medical-Biological Agency, Moscow, Russia \\ ${ }^{2}$ Pirogov Russian National Research Medical University, Moscow, Russia \\ ${ }^{3}$ Institute of Immunology of Federal Medical-Biological Agency, Moscow, Russia
}

\begin{abstract}
Multiple sclerosis (MS) is a chronic demyelinating disease of the central nervous system involving autoimmune mechanisms. MS has been treated as a disorder mediated mainly by T cells for a long time. However, recent findings demonstrate that B lymphocytes are of crucial pathogenetic significance in MS. In patients with MS, B cells can possess both pro-inflammatory and anti-inflammatory effects. The paper reports the main mechanisms of B lymphocyte involvement in the pathogenesis of MS. Diagnostic value of assessing humoral immune parameters in individuals with demyelinating diseases and modern possibility of B cell function modulation are discussed.
\end{abstract}

Keywords: B cells, neurodegeneration, neuroinflammation, multiple sclerosis

Author contribution: Melnikov MV — manuscript writing and editing; Rogovskii VS, Lopatina AV, Volkov Al — manuscript writing; Sviridova AA — manuscript writing and formatting; Boyko AN — study concept and design, manuscript editing

$\triangle$ Correspondence should be addressed: Mikhail V. Melnikov Ostrovitianova, 1, Moscow, 117997; medikms@yandex.ru

Received: 17.07.2021 Accepted: 06.08.2021 Published online: 16.08.2021

DOI: $10.47183 /$ mes.2021.020

\section{МЕХАНИЗМЫ УЧАСТИЯ В-ЛИМФОЦИТОВ В ПАТОГЕНЕЗЕ РАССЕЯННОГО СКЛЕРОЗА}

М. В. Мельников $1,2,3 凶$, В. С. Роговский ${ }^{1,2}$, А. В. Лопатина ${ }^{1,2}$, А. А. Свиридова ${ }^{1,2}$, А. И. Волков ${ }^{1}$ А. Н. Бойко

${ }^{1}$ Федеральный центр мозга и нейротехнологий Федерального медико-биологического агентства, Москва, Россия

${ }^{2}$ Российский национальный исследовательский медицинский университет имени Н. И. Пирогова, Москва, Россия

${ }^{3}$ Институт иммунологии Федерального медико-биологического агентства, Москва, Россия

Рассеянный склероз (РС) - хроническое демиелинизирующее заболевание центральной нервной системы с аутоиммунным механизмом развития. Долгое время РС рассматривали как заболевание, опосредованное преимущественно Т-клетками. Однако исследования последних лет указывают на критическое патогенетическое значение В-лимфоцитов при РС. При РС В-клетки способны оказывать как про-, так и противовоспалительное действие. В статье рассмотрены основные механизмы участия В-клеток в патогенезе РС. Обсуждены диагностическая значимость оценки характеристик гуморального звена иммунной системы при демиелинизирующих заболеваниях, а также современные возможности модуляции функций В-клеток.

Ключевые слова: В-клетки, нейродегенерация, нейровоспаление, рассеянный склероз.

Вклад авторов: М. В. Мельников - написание и редактирование рукописи; В. С. Роговский М, А. В. Лопатина, А. И. Волков - написание рукописи; А. А. Свиридова - написание и форматирование рукописи; А. Н. Бойко - концепция и дизайн исследования, редактирование рукописи

$\bigotimes$ Для корреспонденции: Михаил Валерьевич Мельников

ул. Островитянова, д. 1, г. Москва, 117997; medikms@yandex.ru

Статья получена: 17.07.2021 Статья принята к печати: 06.08.2021 Опубликована онлайн: 16.08.2021

DOI: $10.47183 /$ mes.2021.020

Multiple sclerosis (MS) is a chronic demyelinating and neurodegenerative disease of the central nervous system (CNS) involving autoimmune mechanisms. MS is one of the most complex and socially significant issues of clinical neurology, as confirmed by high prevalence of the disease, constantly growing number of affected people, and severe disabilities in patients with MS, represented mainly by young people aged 18-45 [1].

MS had been treated as a disorder mediated mainly by $T$ cell immune response for a long time. Th1 and Th17 cells (subpopulations of CD4 ${ }^{+} \mathrm{T}$ cells), producing interferon- $\gamma$ (IFN $\gamma$ ) and interleukin-17 (IL17) pro-inflammatory cytokines, were considered of most pathogenetic significance [2].

However, recent findings have shown that B cells play a vital part in the pathogenesis of MS along with $\mathrm{T}$ cells. It is known that $B$ cells are not only able to differentiate into plasma cells and produce antibodies, but also produce cytokines and present antigenes. High diagnostic yield of determining the levels of oligoclonal immunoglobulins and free immunoglobulin $\kappa$ - and $\lambda$-light chains in cerebrospinal fluid, as well as clinical efficacy of anti-B-cell therapy in patients with MS, support B cell involvement in the pathogenesis of MS [3, 4].
The review summarizes the main mechanisms of proinflammatory and anti-inflammatory effects of B lymphocytes involved in the pathogenesis of demyelinating diseases. Diagnostic and prognostic value of assessing humoral immune parameters in individuals with demyelinating disorders are discussed, together with new approaches to B cell functional modulation in individuals with MS.

\section{B lymphocytes: development, differentiation and subpopulations}

\section{B lymphocyte differentiation}

B lymphocytes (B cells) develop from pluripotent hematopoietic stem cells (HSCs) of bone marrow. These cells are a selfmaintaining population; they give rise to lymphoid and myeloid lineage cells. Lymphoid lineage cells give rise to $T$ and $B$ lymphocyte progenitors. IL7 is important for B cell differentiation [5].

The newly formed B cells with an intact B-cell receptor migrate from bone marrow into peripheral blood and secondary lymphoid organs [6]. It is worth noting that the data on B cell differentiation are often controversial, since a wealth of 
information has been obtained during studies involving rodents. It is often difficult to match the populations of human and murine $B$ cells.

In humans, CD10+CD38 high CD24 $4^{\text {high }}$ are the earliest B cells, reconstituting the periphery after B-cell therapy. These B cells are further subdivided into type 1 (T1) and type 2 (T2), as well as CD10 ${ }^{\text {neg }}$ T3 cells, based on incrementally lower expression of CD24 and CD38. These cells are capable of stepwise differentiation into mature- naïve-phenotype $B$ cells in vitro. Mature naïve $B$ cells have a CD10 ${ }^{\text {neg }} C D 38^{\text {low/neg }}$ phenotype [7].

Further differentiation of B cells takes place after antigenic stimulation. Stimulation of $B$ cells is being promoted by interaction of antigen with B-cell receptor (BCR). In contrast to T-cell receptor, BCR recognizes an antigen without contact with the protein of the major histocompatibility complex (MHC). CD19, a co-receptor of BCR complex, is one of the earliest and most specific markers of $B$ cells [8]. CD20 is also a common marker of B cells, expressed by the majority of B cells. However, CD20 is not expressed in terminally differentiating plasmablasts and plasma cells. Unlike CD19, the functional role of CD20 has been studied much less [9].

Antigenic stimulation is followed by a complex process of differentiation, which depends also on the antigen affinity for BCR. In particular, short-lived and long-lived plasma cells, which produce antibodies, as well as memory B cells, are formed during differentiation. It's interesting that, according to modern concept, memory B cells develop from B cells with lower affinity for antigen, which provides an opportunity of B-cell receptor fast adaptation to modified antigen (for example, resulting from mutation of the virus) [10].

\section{B lymphocyte subpopulations}

\section{Memory B cells}

Memory B cells are the long-lived resting cells, which are able to respond rapidly to antigen reappearance. In cases where the levels of circulating antibodies are insufficient for immediate neutralization and elimination of pathogens, the memory B cell expansion takes place. It is worth noting that memory B cells are localized to sites with maximum probability of contact with antigens. Moreover, macrophages (CD169+), which are able to present antigens to B cells, are represented this wide within these sites. Antigens are presented both to naïve $B$ cells and memory B cells [10].

Thus, two types of B-cell memory can be distinguished. Realization of type 1 involves antibodies, produced by longlived plasma cells. Human plasma cells are characterized by co-expression of CD138 and CD38, which makes it possible to identify plasma cells in bone marrow or single cell suspensions, isolated from tissues by multicolor flow cytometry. These terminally differentiated $\mathrm{B}$ cells lose the ability to express CD19 and CD20 (markers of B cells) on the cell surface, while retaining CD27 expression [8].

Type 2 B-cell memory is mediated by memory B cells, which are in the resting state and are recruited in case of insufficient immune response, generated by type 1 B-cell memory. Therefore, it is worth mentioning that the lack of specific antibodies in blood plasma should not be considered the lack of capability to generate the repeated immune response in memory B cells.

There are several types of memory B cells, which are classified based on their origin, differential expression of CD27, and expressed immunoglobulin isotype. There are three main characteristic sites, memory $B$ cells originate from: spleen, germinal centers (structures located in secondary lymphoid organs, especially in lymph nodes, where mature $B$ cells proliferate and differentiate), and lamina propria of intestinal mucosa. Memory cells, originating from spleen, are characterized by production of markers CD27-lgG+. Memory $B$ cells of germinal centers express $\mathrm{CD}^{2} 7^{+} \operatorname{lgM}{ }^{+} \lg D^{-}$. These cells are characterized by switching from expression of IgM to expression of $\mathrm{CD}_{2} 7^{+} \operatorname{lgG} / \lg A^{+}$. Intestinal memory B cells express CD27- $\lg \mathrm{A}^{+}[11]$.

According to current understanding of the issue, human memory $\mathrm{B}$ cells in blood and bone marrow can be divided into three main populations: $C D 19^{+} \mathrm{CD}_{2} 7^{+} \lg \mathrm{M}^{+} \lg \mathrm{D}^{+}$(similar to marginal zone B cells), CD19+ ${ }^{+} D 27^{+} \operatorname{lgM}{ }^{+} \operatorname{lgD}{ }^{-}$(i.e., IgM positive only), and immunoglobulin class-switched cells $\mathrm{CD}{ }^{+} \mathrm{CD} 27+\operatorname{lgM}^{-}\left(\operatorname{lgG}^{+}\right.$or $\left.\lg \mathrm{A}^{+}\right)[10]$.

After their activation and differentiation in germinal centers, B cells develop into high affinity B cells, which migrate to bone marrow, where they can persist for a long time without any antigenic stimulation, providing the basis for long-term humoral immunity [10].

Memory B cells can be also localized in the body areas being the gateways and predominant areas of infection dissemination; such cells are memory $B$ cells, which reside in tissue [12]. After representation of the antigen, B cells begin to rapidly proliferate and differentiate into plasma cells. Furthermore, these cells can enter germinal centers again for further retraining, i.e. to increase their affinity and shift the class of immunoglobulins produced [10].

It is worth noting that follicular CD4 ${ }^{+} \mathrm{T}$ cells (follicular helper $\mathrm{T}$ cells or Tfh cells), which promote memory B cell differentiation into plasma cells through IL21 production, play a vital part in germinal centers. It is known that IL21 is an important cytokine involved in the pathogenesis of MS, which enables differentiation of Th17 cells. According to the latest data, Tfh cells play an important role in Th17-induced neuroinflammation and therefore are a potential target for MS [10, 13].

\section{Regulatory B cells}

The recently identified subpopulation of regulatory $B$ cells $\left(B_{\text {reg }}\right)$, which produce IL10 and are able to suppress immune response to foreign antigens and autoantigens, is of great interest $[13,14]$. Types of $B_{\text {reg }}$, most frequently found in literature, are as follows: B cells CD24 $4^{\text {high }} \mathrm{CD} 38^{\text {high }}$ and $\mathrm{CD} 27^{\text {int }} \mathrm{CD} 38^{\text {high }}$. Breg are able to stimulate differentiation of $C D 4^{+} T$ cells into regulatory $T$ cells $\left(T_{\text {reg }}\right)$, inhibit Th1 immune response and differentiation of Th17 cells. Breg can also suppress production of IFN- $\alpha$ by dendritic cells. Suppressor activity of $B_{\text {reg }}$ decreases in individuals with autoimmune disorders [14].

\section{Mechanisms of B cell involvement in the immunopathogenesis of MS (antibodies, cytokines, antigen presentation)}

B cells are involved in the pathogenesis of MS through various mechanisms, such as antigen presentation to T cells, secretion of pro-inflammatory and anti-inflammatory cytokines, and production of autoantibodies [15].

$\mathrm{B}$ cells are professional antigen-presenting cells. They specifically recognize even low concentrations of antigens and constitutively express the major histocompatibility complex $(\mathrm{MHC})$ class II molecules and co-stimulatory molecules, which enables B cells to prime T cells and, in turn, induce their own differentiation into memory cells and plasma cells that produce 
antibodies [16, 17]. The increased activation of infiltrating $T$ cells in the CNS, which then realize their damaging effects in brain and spinal cord, is possibly due to these processes [17].

Secretion of cytokines by B cells support neuroinflammation. $B$ cells of patients with MS are characterized by pro-inflammatory cytokine profile. These cells produce increased amounts of IL6, lymphotoxin- $\alpha$ and tumor necrosis factor- $\alpha$ (TNF $\alpha$ ), along with reduced production of anti-inflammatiry IL10 [17]. It is found that anti-B-cell therapy suppresses autoimmune reactions via depletion of IL6-producing B lymphocytes [18].

MS is also characterized by increased intrathecal synthesis of IgG. Elevated IgG levels in cerebrospinal fluid are likely to be associated with elevated levels of circulating antibodies, particularly, with selective elevation of IgG1 and lgG3 subclass levels. Antibody production by circulating B cells contributes significantly to the pathogenesis of MS [19].

It is important that B lymphocyte involvement in the pathogenesis of MS is associated with $\mathrm{B}$ lymphocyte functioning both in the periphery and in the CNS. It is shown that ectopic lymphoid follicles, represented mainly by B lymphocytes, are formed in the meninges of patients with secondary progressive MS. It is believed that such B-cell structures are particularly likely to contribute to cortical demyelination and disease progression. Moreover, it has recently been found that meningeal B-cell follicles are formed from the earliest stages of demyelination, which may explain neurodegenerative changes at the disease onset [20, 21].

\section{Diagnostic and prognostic value of assessing humoral immune parameters in individuals with demyelinating diseases}

Regardless of the successes in understanding the pathogenesis of MS, no biomarkers, enabling early diagnosis of MS with high specificity and sensitivity, have been found. To date, among many immunological parameters assessed in individuals with MS, the humoral immune parameters (particularly, oligoclonal bands of immunoglobulins and IgG in cerebrospinal fluid) are of the greatest diagnostic and prognostic value [22-24].

Oligoclonal bands of immunoglobulins are determined in paired samples of blood serum and cerebrospinal fluid. The bands are formed by $\lg G$ and $\lg M$, produced by plasma cells of the CNS. Simultaneous presence of such bands in cerebrospinal fluid and their absence in blood serum indicate the increased intrathecal antibody production and are associated with MS (oligoclonal bands of immunoglobulins present in cerebrospinal fluid and abscent in blood serum are found in 95\% of patients with MS). However, it is worth mentioning that oligoclonal bands of immunoglobulins are not specific for MS and can be found in individuals with different inflammatory disorders of the CNS [23]. Thus, this is an additional indicator to be used for diagnosis of MS; it is rather used to bear out the nature of the disorder when trying to exclude other inflammatory disorders of the CNS.

Assessment of free immunoglobulin $\kappa$-light chains in cerebrospinal fluid is highly sensitive and specific for MS [25].

Prognostic value of assessing oligoclonal bands of immunoglobulins and free immunoglobulin $\kappa$-light chains in cerebrospinal fluid in order to estimate the risk of conversion from clinically isolated syndrome (CIS) and radiologically isolated syndrome (RIS) (early forms of demyelinization) is also discussed. Thus, several major studies have shown that the presence of oligoclonal bands of immunoglobulins in patients with CIS and RIS increases the risk of conversion in individuals with MS [25-27].

Humoral immune parameters are also studied in individuals with different disorders of the CNS. For example, antibodies to aquaporin-4, as well as to myelin oligodendrocyte glycoprotein (MOG), are of high value for diagnosis of neuromyelitis optica spectrum disorder (NMOSD) and MOG-antibody associated diseases respectively [28].

\section{Impact of anti-B-cell therapy on the course of MS}

Understanding of the anti-B-cell therapy (especially based on monoclonal anti-CD20 antibody) clinical efficiency in individuals with MS has recently become one of the most important events in treatment of this disorder. Moreover, to date, anti-B-cell therapy with ocrelizumab is the only method for treatment of primary progressive MS with proven efficacy [29]. Ocrelizumab and oftamumab (the latter has not yet been approved in Russian Federation) are being actively used in individuals with active relapsing MS and secondary progressive MS with exacerbations. The need to determine the criteria for such medication personalized prescription, i. e. identification of prognostic markers of optimal/suboptimal response to therapy, is one of the main issues related to anti-B-cell therapy prescription. Optimal drug dose and dosage frequency are the other issue.

From this perspective, determining the percentage of the immunological memory B cells $\left(\mathrm{CD} 19^{+} \mathrm{CD} 27^{+}\right)$attracts the greatest attention [30, 31]. Currently, this method is used (offlabel) in the countries of the European Union and in the USA within the framework of personalized approach to treatment of patients, who receive rituximab and ocrelizumab for treatment of MS and neuromyelitis optica [30]. Control of memory B cell levels aimed at optimization of rituximab therapy in individuals with neuromyelitis optica spectrum disorders (NMOSD) is recommended by the French cohort on NMO and related disorders (NOMADMUS) [32]. Memory B cells in the peripheral blood mononuclear cell fraction were analyzed within the framework of several clinical trials in order to optimize treatment of neuromyelitis optica with rituximab [23-35]. In the course of one of these trials 100 patients with neuromyelitis optica were treated with rituximab during an average period of 67 months (achieving the levels of memory B cells of $>0.05 \%$ of the peripheral blood mononuclear cell number in two years and of $>0.1 \%$ in the following years) [34]. The annualized relapse rate was reduced from 2.4 to 0.1 upon treatment, and disability improved or stabilized in $96 \%$ of patients.

However, there are no known trials, during which the recording of individual clinical, brain imaging and immunological parameters has served as an occasion for modifying the protocol of MS treatment with alemtuzumab, cladribine, ocrelizumab, with the exception of adverse reactions, including lymphopenia.

When studying the mechanism of action of the listed above medications, it has been found, that selective apoptosis of the immunological memory B cell pool is a key aspect of these medications efficiency in treatment of MS and NMOSD. Thus, alemtuzumab, one of the highly effective medications for treatment of MS, induces $T$ and B cell death followed by rapid recovery of the population of immature and mature $B$ cells, along with the long-term decrease in the levels of the CD19+CD27 ${ }^{+}$memory B cells [36]. Analysis of lymphocyte subpopulations, performed within the framework of cladribine tablets clinical trial, showed that the decrease in the levels of $\mathrm{CD}^{+} \mathrm{T}$ cells was $40-45 \%$, and the decrease in the levels of CD8 ${ }^{+}$cells was $15-20 \%$ throughout the year after using the medication. However, the decrease in the levels of CD19+ B cells was more sufficient $[37,38]$. It should be noted that high clinical efficacy of cladribine cannot be explained by the 
Table. Effects of medications, modifying the course of MS, on B cell functions in EAE and MS

\begin{tabular}{|c|c|c|c|}
\hline Therapy & Disorder & Effects on B lymphocytes & Authors \\
\hline \multirow[t]{2}{*}{ Glatiramer acetate } & EAE & Increased production of IL4, IL10 and IL13 along with reduced production of IL6, IL12 and TNF $\alpha$ by B cells & {$[44,45]$} \\
\hline & MS & $\begin{array}{l}\text { Reduced expression of CXCR5 and ICAM-3 in B lymphocytes. Reduced production of IL6 and TNF } \alpha \text {, } \\
\text { increased production of IL10 by B cells }\end{array}$ & {$[44,46]$} \\
\hline \multirow[t]{2}{*}{ IFN $\beta$} & EAE & Increased number of IL10-producing $B_{\text {reg }}$ cells & [47] \\
\hline & MS & Suppressed expression of IL1 $\beta$, IL23 genes. Increased number of IL10-producing $B_{\text {reg }}$ cells & {$[47,48]$} \\
\hline \multirow[t]{2}{*}{ Dimethyl fumarate } & EAE & Suppressed expression of MHC II in B cells B, reduced production of GM-CSF, TNF $\alpha$ and IL6 by B cells & {$[49,50]$} \\
\hline & MS & Reduced number of $\mathrm{CD} 19^{+} \mathrm{CD} 27^{+}$memory B cells. Reduced production of GM-CSF, IL6 and TNF $\alpha$ by B cells & {$[49,51]$} \\
\hline \multirow[t]{2}{*}{ Teriflunomide } & EAE & Reduced number of $\mathrm{B}$ cells migrating to CNS & [52] \\
\hline & MS & Reduced total number of B cells & {$[53,54]$} \\
\hline \multirow[t]{2}{*}{ Fingolimod } & EAE & Prevention of B cell follicle formation in meninges & [50] \\
\hline & MS & $\begin{array}{l}\text { Reduced number of circulating B cells. Reduced production of TNF } \alpha \text { and increased production of IL10 } \\
\text { by B cells }\end{array}$ & {$[49,50,54]$} \\
\hline Natalizumab & MS & $\begin{array}{l}\text { Increased number of } B_{\text {reg }} \text { cells circulating in peripheral blood. Reduced number of B cells in cerebrospinal } \\
\text { fluid }\end{array}$ & {$[50,55]$} \\
\hline \multirow{2}{*}{ Ocrelizumab } & EAE & Reduced number of B cells in bone marrow, lymph nodes and spleen & [56] \\
\hline & MS & Reduced number of $\mathrm{CD} 20^{+} \mathrm{B}$ cells & {$[53,57]$} \\
\hline Cladribine & MS & Reduced number of circulating memory B cells. Increased production of IL 10 by B cells & [53] \\
\hline Alemtuzumab & MS & Reduced number of circulating B cells & {$[49,50]$} \\
\hline
\end{tabular}

decrease in $\mathrm{CD}^{+}{ }^{+} \mathrm{T}$ cells only; studying monoclonal anti-CD4 antibodies showed that the decrease in the levels of $\mathrm{CD}^{+}$ $\mathrm{T}$ cells resulted in slightly reduced MS relapse rate by 60 $70 \%$ [39]. The cladribine tablets clinical trial revealed the dose-dependent effect (between the doses of $5.25 \mathrm{mg} / \mathrm{kg}$ and $3.5 \mathrm{mg} / \mathrm{kg}$ ) on the CD4 and CD8 cell populations, but not on B cells [37]. Taking into account the same results of using both doses of cladribine, the effects of this medication were attributed to its effects excerted primarily on B cells [38]. In contrast, recovery of memory B cell population upon treatment with alemtuzumab was combined with recurrence of MS activity and the need for repeated courses of treatment $[38,40-42]$.

It has been shown that anti-B-cell therapy with monoclonal anti-CD20 antibody is highly effective in individuals with MS. The use of ocrelizumab results in significantly decreased levels of CD19+ B cells. That is why administration of the drug every 6 months may be too much for some patients. Thus, during phase II clinical trial of ocrelizumab in individuals with relapse MS, where the experimental groups, which received placebo and IFN $\beta$, were treated by ocrelizumab after 24 weeks, and then received the medication after 24, 48, 72 weeks and were followed-up up to week 144 , the relapse rate and disability progression were low within 18 months after the last administration of the drug [43].

It is important to mention that B cell functions are affected not only by anti-B-cell therapy, but also by other drugs, modifying the course of MS. This could explain these medications' clinical efficacy. Effects of other disease-modifying treatments of MS on B cell functions in animals with experimental autoimmune encephalomyelitis (EAE) and individuals with MS are presented in the Table.

\section{CONCLUSIONS}

The importance of humoral immunity in the pathogenesis and treatment of demyelinating diseases of the CNS is not subject to doubt. However, the mechanisms mediating the role of $\mathrm{B}$ cells in such disorders are poorly understood. Migration of B cells from the periphery into CNS through blood-brain barrier, importance of B cells at the early stages of demyelination, and effects of anti-B-cell therapy on B cells of the CNS are just some of many issues to be clarified.

\section{References}

1. Boyko A, Melnikov M. Prevalence and incidence of multiple sclerosis in Russian Federation: 30 years of studies. Brain Sci. 2020 May 18; 10 (5): 305. DOI: 10.3390/brainsci10050305.

2. Kamali AN, Noorbakhsh SM, Hamedifar H, Jadidi-Niaragh F, Yazdani R, Bautista JM, et al. A role for Th1-like Th17 cells in the pathogenesis of inflammatory and autoimmune disorders. Mol Immunol. 2019 Jan; 105: 107-15. DOI: 10.1016/j. molimm.2018.11.015.

3. Ziemssen T, Akgün K, Brück W. Molecular biomarkers in multiple sclerosis. J Neuroinflammation. 2019 Dec 23; 16 (1): 272. DOl: 10.1186/s12974-019-1674-2.

4. Milo R. Therapies for multiple sclerosis targeting B cells. Croat Med J. 2019 Apr 30; 60 (2): 87-98. DOI: 10.3325/cmj.2019.60.87.

5. Corfe SA, Paige CJ. The many roles of IL7 in B cell development; mediator of survival, proliferation and differentiation. Semin Immunol.
2012; 24 (3), 198-208. DOI: 10.1016/.smim.2012.02.001.

6. Bemark M. Translating transitions - how to decipher peripheral human B cell development. J Biomed Res. 2015; 29 (4): 264-84. DOI: 10.7555/JBR.29.20150035.

7. Kaminski DA, Wei C, Qian Y, Rosenberg AF, Sanz I. Advances in human B cell phenotypic profiling. Front Immunol 3. 2012; 302. DOI: 10.3389/fimmu.2012.00302.

8. Khodadadi L, Cheng Q, Radbruch A, Hiepe F. The maintenance of memory plasma cells. Front Immunol 10. 2019; 721. DOl: 10.3389/fimmu.2019.00721.

9. Pavlasova $\mathrm{G}$, Mraz M. The regulation and function of CD20: an "enigma" of B-cell biology and targeted therapy. Haematologica. 2020; 105 (6): 1494-506. DOI: 10.3324/haematol.2019.243543.

10. Palm AE, Henry C. Remembrance of things past: long-term B cell memory after infection and vaccination. Front Immunol. 2019; 10: 
1787. DOI: 10.3389/fimmu.2019.01787.

11. Luz EC, Damaris EL. "Introduction to T and B lymphocytes," in autoimmunity: from bench to bedside. El Rosario University Press, 2013.

12. Adachi $Y$, Onodera $T$, Yamada $Y$, Daio R, Tsuiji M, Inoue $T$, et al. Distinct germinal center selection at local sites shapes memory $\mathrm{B}$ cell response to viral escape. J Exp Med. 2015; 212 (10), 170923. DOI: $10.1084 / \mathrm{jem} .20142284$.

13. Quinn JL, Kumar G, Agasing A, Ko RM, Axtell RC. Role of TFH cells in promoting $T$ helper 17 -induced neuroinflammation. Front Immunol. 2018; 9: 382. DOI: 10.3389/fimmu.2018.00382.

14. Atisha-Fregoso $\mathrm{Y}, \mathrm{Zou} \mathrm{YR}$, Diamond B. "B cells and generation of antibodies". In: Dubois' Lupus Erythematosus and Related Syndromes. Elsevier, 2019; 101-15.

15. Sospedra M. B cells in multiple sclerosis. Curr Opin Neurol. 2018; 31 (3): 256-262. DOI: 10.1097/WCO.000000000000563.

16. Adler LN, Jiang W, Bhamidipati K, Millican M, Macaubas C, et al. The other function: class II-restricted antigen presentation by B cells. Front Immunol. 2017; 8: 319. DOI: 10.3389/ fimmu.2017.00319.

17. Hausser-Kinzel S, Weber MS. The role of B cells and antibodies in multiple sclerosis, neuromyelitis optica, and related disorders. Front Immunol. 2019; 10: 201. DOI: 10.3389/fimmu.2019.00201.

18. Barr TA, Shen P, Brown S, Lampropoulou V, Roch T, Lawrie S, et al. B cell depletion therapy ameliorates autoimmune disease through ablation of IL6-producing B cells. J Exp Med. 2012; 209 (5): 1001-10. DOI: 10.1084/jem.20111675.

19. Yu X, Graner M, Kennedy PGE, Liu Y. The role of antibodies in the pathogenesis of multiple sclerosis. Front Neurol. 2020; 11: 533388. DOI: 10.3389/fneur.2020.533388.

20. Negron A, Stüve O, Forsthuber TG. Ectopic lymphoid follicles in multiple sclerosis: Centers for Disease Control. Front Neurol. 2020 Dec 8; 11: 607766. DOI: 10.3389/fneur.2020.607766.

21. Bell L, Lenhart A, Rosenwald A, Monoranu CM, Berberich-Siebelt $F$. Lymphoid aggregates in the CNS of progressive multiple sclerosis patients lack regulatory T cells. Front Immunol. 2020 Jan 15; 10: 3090. DOI: 10.3389/fimmu.2019.03090.

22. Ziemssen T, Akgün K, Brück W. Molecular biomarkers in multiple sclerosis. J Neuroinflammation. 2019 Dec 23; 16 (1): 272. DOI: 10.1186/s12974-019-1674-2

23. Schwenkenbecher P, Konen FF, Wurster $U$, Jendretzky KF, Gingele $S$, Sühs KW, et al. The persisting significance of oligoclonal bands in the dawning era of kappa free light chains for the diagnosis of multiple sclerosis. Int J Mol Sci. 2018 Nov 29; 19 (12): 3796. DOl: 10.3390/ijms19123796.

24. Lefvert $A$, Link $H$. IgG production within the central nervous system: a critical review of proposed formulae. Ann Neurol. 1985; 17: 13-20. DOI: 10.1002/ana.410170105.

25. Tintore M, Rovira À, Río J, Otero-Romero S, Arrambide G, Tur C, et al. Defining high, medium and low impact prognostic factors for developing multiple sclerosis. Brain. 2015 Jul; 138 (Pt 7): 186374. DOI: 10.1093/brain/awv105.

26. Kuhle J, Disanto G, Dobson R, et al. Conversion from clinically isolated syndrome to multiple sclerosis: A large multicentre study. Mult Scler. 2015; 21 (8): 1013-24.

27. Lebrun-Frenay C, Kantarci O, Siva A, Sormani MP, Pelletier D, Okuda DT. 10-year RISC study group on behalf of SFSEP, OFSEP. Radiologically isolated syndrome: 10-year risk estimate of a clinical event. Ann Neurol. 2020 Aug; 88 (2): 407-17. DOl: 10.1002/ana.25799.

28. Hor JY, Asgari N, Nakashima I, Broadley SA, Leite MI, Kissani N, et al. Epidemiology of neuromyelitis optica spectrum disorder and its prevalence and incidence worldwide. Front Neurol. 2020 Jun 26; 11: 501. DOI: 10.3389/fneur.2020.00501.

29. Greenfield AL, Hauser SL. B-cell therapy for multiple sclerosis: entering an era. Ann Neurol. 2018 Jan; 83 (1): 13-26. DOl: 10.1002/ana.25119.

30. Baker D, Marta M, Pryce G, Giovannoni G, Schmierer K. Memory $B$ cells are major targets for effective immunotherapy in relapsing multiple sclerosis. E Bio Medicine. 2017; 16: 41-50.

31. Bose T. Role of immunological memory cells as a therapeutic target in multiple sclerosis. Brain Sci. 2017; 7 (11): E148.

32. Ciron J, Audoin B, Bourre B, Brassat D, Durand-Dubief F, Laplaud D, et al. NOMADMUS group, under the aegis of OFSEP, SFSEP.
Recommendations for the use of Rituximab in neuromyelitis optica spectrum disorders Rev Neurol (Paris). 2018; 174 (4): 255-64.

33. Kim SH, Kim W, Li XF, Jung IJ, Kim HJ. Repeated treatment with rituximab based on the assessment of peripheral circulating memory B cells in patients with relapsing neuromyelitis optica over 2 years. Arch Neurol. 2011; 68, 1412-20.

34. Kim SH, Jeong $\mathrm{H}$, Hyun JW, Joung $A$, Jo HJ, Hwang $\mathrm{SH}$, et al. Treatment outcomes with rituximab in 100 patients with neuromyelitis optica: influence of FCGR3A polymorphisms on the therapeutic response to rituximab. JAMA Neurol. 72: 989-95.

35. Kim SH, Huh SY, LeeSJ, Joung A, Kim HJ. A5-yearfollow-up ofrituximab treatment in patients with neuromyelitis optica spectrum disorder. JAMA Neurol. 2013; 70: 1110-7.

36. Thompson SA, Jones JL, Cox AL, et al. B-cell reconstitution and BAFF after alemtuzumab (CAMPATH-1H) treatment of multiple sclerosis. J Clin Immunol. 2010; 30: 99-105.

37. Duddy M, Niino M, Adatia F, et al. Distincteffectorcytokineprofil esofmemoryand naive human B cell subsets and implication in multiple sclerosis. J Immunol. 2007; 178: 6092-9.

38. Giovannoni G, Cohen JA, Coles AJ, Hartung HP, Havrdova E, Selmaj KW, et al. CARE-MS II Investigators. Alemtuzumab improves preexisting disability in active relapsing-remitting MS patients. Neurology. 2016 Nov 8; 87 (19): 1985-92.

39. Van Oosten BW, Lai M, Hodgkinson S, et al. Treatmentofmultiple sclerosiswith the monoclonal anti-CD4 antibody CM-T412:results of a randomized, double-blind, placebo-controlled, MR-monitored phase II trial. Neurology. 1997; 49: 351-7.

40. Ceronie B, Jacobs BM, Baker D, Dubuisson N, Mao Z, Ammoscato $F$, et al. Cladribine treatment of multiple sclerosis is associated with depletion of memory B cells. J Neurol. 2018 May; 265 (5): 1199-209.

41. Giovannoni G, Cohen JA, Coles AJ, Hartung HP, Havrdova E, Selmaj KW, et al. CARE-MS II Investigators. Alemtuzumab improves preexisting disability in active relapsing-remitting MS patients. Neurology. 2016 Nov 8; 87 (19): 1985-92.

42. Havrdova E, Arnold DL, Cohen JA, Hartung HP, Fox EJ, Giovannoni G, et al. CARE-MS I and CAMMS03409 Investigators. Alemtuzumab CARE-MS I 5-year follow-up: Durable efficacy in the absence of continuous MS therapy. Neurology. 2017 Sep 12; 89 (11): 1107-16. Neurology. 2018 Apr 17; 90 (16): 755.

43. Genovese MC, Kaine JL, Lowenstein MB, et al. Ocrelizumab, a humanized antiCD20 monoclonalantibody, inthe treatment of patients with rheumatoidarthritis: a phase $1 / / 1$ randomized, blinded, placebo-controlled, dose-ranging study. Arthritis Rheum. 2008; 58: 2652-61.

44. Kuerten S, Jackson LJ, Kaye J, Vollmer TL. Impact of glatiramer acetate on B cell-mediated pathogenesis of multiple sclerosis. CNS Drugs. 2018; 32 (11): 1039-51.

45. Begum-Haque S, Christy M, Ochoa-Reparaz J, Nowak EC, Mielcarz D, Haque A, et al. Augmentation of regulatory B cell activity in experimental allergic encephalomyelitis by glatiramer acetate. J Neuroimmunol. 2011 Mar; 232 (0): 136-44.

46. Ireland SJ, Guzman AA, O Brien DE, Hughes S, Greenberg B, Flores $\mathrm{A}$, et al. The effect of glatiramer acetate therapy on functional properties of $\mathrm{B}$ cells from patients with relapsing-remitting multiple sclerosis. JAMA Neurol. 2014 Nov; 71 (11): 1421-8.

47. Schubert RD, Hu Y, Kumar G, Szeto S, Abraham P, Winderl J, et al. Interferon- $\beta$ treatment requires B cells for efficacy in neuroautoimmunity. J Immunol. 2015 Mar 1; 194 (5): 2110-6.

48. Ramgolam VS, Sha Y, Marcus KL, Choudhary N, Troiani L, Chopra $\mathrm{M}$, et al. B cells as a therapeutic target for IFN- $\beta$ in relapsingremitting multiple sclerosis. J Immunol. 2011; 186 (7): 4518-26.

49. Sabatino JJ, Zamvil SS, Hauser SL. B-cell therapies in multiple sclerosis. Cold Spring Harb Perspect Med. 2019 Feb; 9 (2): a032037.

50. Lehmann-Horn K, Kinzel S, Weber MS. Deciphering the role of B cells in multiple sclerosis-towards specific targeting of pathogenic function. Int J Mol Sci. 2017 Oct; 18 (10): 2048.

51. Gregson A, Thompson K, Tsirka SE, Selwood DL. Emerging small-molecule treatments for multiple sclerosis: focus on B cells. F1000Res. 2019; 8: F1000 Faculty Rev-245.

52. Braley TJ, Segal BM. B-cell targeting agents in the treatment of multiple sclerosis. Curr Treat Options Neurol. 2013 Jun; 15 (3): 259-69. 
53. Traub JW, Häusser-Kinzel S, Weber MS. Differential effects of MS therapeutics on B cells-implications for their use and failure in AQP4-positive NMOSD patients. Int J Mol Sci. 2020 Jul; 21 (14): 5021.

54. Claes N, Fraussen J, Stinissen P, Hupperts R, Somers V. B cells are multifunctional players in multiple sclerosis pathogenesis: insights from therapeutic interventions. Front Immunol. 2015; 6: 642.

55. Traub JW, Pellkofer HL, Grondey K, Seeger I, Rowold C, Brück W, et al. Natalizumab promotes activation and pro-inflammatory differentiation of peripheral $\mathrm{B}$ cells in multiple sclerosis patients. $\mathrm{J}$
Neuroinflammation. 2019; 16: 228

56. Häusler D, Häusser-Kinzel S, Feldmann L, Torke S, Lepennetier $G$, Bernard CCA, et al. Functional characterization of reappearing $B$ cells after anti-CD20 treatment of CNS autoimmune disease. Proc Natl Acad Sci USA. 2018 Sep 25; 115 (39): 9773-8.

57. Fernández-Velasco Jl, Kuhle J, Monreal E, et al. Effect of ocrelizumab in blood leukocytes of patients with primary progressive MS. Neurol Neuroimmunol Neuroinflamm. 2021 Mar; 8 (2): e940.

\section{Литература}

1. Boyko A, Melnikov M. Prevalence and incidence of multiple sclerosis in Russian Federation: 30 years of studies. Brain Sci. 2020 May 18; 10 (5): 305. DOI: 10.3390/brainsci10050305.

2. Kamali AN, Noorbakhsh SM, Hamedifar H, Jadidi-Niaragh F, Yazdani R, Bautista JM, et al. A role for Th1-like Th17 cells in the pathogenesis of inflammatory and autoimmune disorders. Mol Immunol. 2019 Jan; 105: 107-15. DOI: 10.1016/j. molimm.2018.11.015.

3. Ziemssen T, Akgün K, Brück W. Molecular biomarkers in multiple sclerosis. J Neuroinflammation. 2019 Dec 23; 16 (1): 272. DOI: 10.1186/s12974-019-1674-2.

4. Milo R. Therapies for multiple sclerosis targeting B cells. Croat Med J. 2019 Apr 30; 60 (2): 87-98. DOI: 10.3325/cmj.2019.60.87.

5. Corfe SA, Paige CJ. The many roles of IL7 in B cell development; mediator of survival, proliferation and differentiation. Semin Immunol. 2012; 24 (3), 198-208. DOI: 10.1016/j.smim.2012.02.001.

6. Bemark M. Translating transitions - how to decipher peripheral human B cell development. J Biomed Res. 2015; 29 (4): 264-84. DOI: 10.7555/JBR.29.20150035.

7. Kaminski DA, Wei C, Qian Y, Rosenberg AF, Sanz I. Advances in human B cell phenotypic profiling. Front Immunol 3. 2012; 302. DOI: 10.3389/fimmu.2012.00302.

8. Khodadadi L, Cheng Q, Radbruch A, Hiepe F. The maintenance of memory plasma cells. Front Immunol 10. 2019; 721. DOI: 10.3389/fimmu.2019.00721.

9. Pavlasova G, Mraz M. The regulation and function of CD20: an "enigma" of B-cell biology and targeted therapy. Haematologica. 2020; 105 (6): 1494-506. DOI: 10.3324/haematol.2019.243543.

10. Palm AE, Henry C. Remembrance of things past: long-term B cell memory after infection and vaccination. Front Immunol. 2019; 10: 1787. DOI: 10.3389/fimmu.2019.01787.

11. Luz EC, Damaris EL. "Introduction to T and B lymphocytes," in autoimmunity: from bench to bedside. El Rosario University Press, 2013.

12. Adachi $Y$, Onodera $T$, Yamada $Y$, Daio R, Tsuiji M, Inoue $T$, et al. Distinct germinal center selection at local sites shapes memory $B$ cell response to viral escape. J Exp Med. 2015; 212 (10), 170923. DOI: $10.1084 / \mathrm{jem} .20142284$.

13. Quinn JL, Kumar G, Agasing A, Ko RM, Axtell RC. Role of TFH cells in promoting $T$ helper 17 -induced neuroinflammation. Front Immunol. 2018; 9: 382. DOI: 10.3389/fimmu.2018.00382.

14. Atisha-Fregoso $\mathrm{Y}$, Zou YR, Diamond B. "B cells and generation of antibodies". In: Dubois' Lupus Erythematosus and Related Syndromes. Elsevier, 2019; 101-15.

15. Sospedra M. B cells in multiple sclerosis. Curr Opin Neurol. 2018; 31 (3): 256-262. DOI: 10.1097/NCO.000000000000563.

16. Adler LN, Jiang W, Bhamidipati K, Millican M, Macaubas C, et al. The other function: class II-restricted antigen presentation by B cells. Front Immunol. 2017; 8: 319. DOI: 10.3389/ fimmu.2017.00319.

17. Hausser-Kinzel S, Weber MS. The role of B cells and antibodies in multiple sclerosis, neuromyelitis optica, and related disorders. Front Immunol. 2019; 10: 201. DOI: 10.3389/fimmu.2019.00201.

18. Barr TA, Shen P, Brown S, Lampropoulou V, Roch T, Lawrie S, et al. B cell depletion therapy ameliorates autoimmune disease through ablation of IL6-producing B cells. J Exp Med. 2012; 209 (5): 1001-10. DOl: 10.1084/jem.20111675.

19. Yu X, Graner M, Kennedy PGE, Liu Y. The role of antibodies in the pathogenesis of multiple sclerosis. Front Neurol. 2020; 11: 533388. DOI: 10.3389/fneur.2020.533388.
20. Negron A, Stüve O, Forsthuber TG. Ectopic lymphoid follicles in multiple sclerosis: Centers for Disease Control. Front Neurol. 2020 Dec 8; 11: 607766. DOI: 10.3389/fneur.2020.607766.

21. Bell L, Lenhart A, Rosenwald A, Monoranu CM, Berberich-Siebelt F. Lymphoid aggregates in the CNS of progressive multiple sclerosis patients lack regulatory T cells. Front Immunol. 2020 Jan 15; 10: 3090. DOI: 10.3389/fimmu.2019.03090.

22. Ziemssen T, Akgün K, Brück W. Molecular biomarkers in multiple sclerosis. J Neuroinflammation. 2019 Dec 23; 16 (1): 272. DOI: 10.1186/s12974-019-1674-2.

23. Schwenkenbecher P, Konen FF, Wurster U, Jendretzky KF, Gingele S, Sühs KW, et al. The persisting significance of oligoclonal bands in the dawning era of kappa free light chains for the diagnosis of multiple sclerosis. Int J Mol Sci. 2018 Nov 29; 19 (12): 3796. DOI: 10.3390/ijms19123796.

24. Lefvert $A$, Link $H$. IgG production within the central nervous system: a critical review of proposed formulae. Ann Neurol. 1985; 17: 13-20. DOI: 10.1002/ana.410170105.

25. Tintore M, Rovira À, Río J, Otero-Romero S, Arrambide G, Tur C, et al. Defining high, medium and low impact prognostic factors for developing multiple sclerosis. Brain. 2015 Jul; 138 (Pt 7): 186374. DOI: 10.1093/brain/awv105

26. Kuhle J, Disanto G, Dobson R, et al. Conversion from clinically isolated syndrome to multiple sclerosis: A large multicentre study. Mult Scler. 2015; 21 (8): 1013-24.

27. Lebrun-Frenay C, Kantarci O, Siva A, Sormani MP, Pelletier D, Okuda DT. 10-year RISC study group on behalf of SFSEP, OFSEP. Radiologically isolated syndrome: 10-year risk estimate of a clinical event. Ann Neurol. 2020 Aug; 88 (2): 407-17. DOI: 10.1002/ana.25799.

28. Hor JY, Asgari N, Nakashima I, Broadley SA, Leite MI, Kissani N, et al. Epidemiology of neuromyelitis optica spectrum disorder and its prevalence and incidence worldwide. Front Neurol. 2020 Jun 26; 11: 501. DOI: 10.3389/fneur.2020.00501.

29. Greenfield AL, Hauser SL. B-cell therapy for multiple sclerosis: entering an era. Ann Neurol. 2018 Jan; 83 (1): 13-26. DOI: 10.1002/ana.25119.

30. Baker D, Marta M, Pryce G, Giovannoni G, Schmierer K. Memory $B$ cells are major targets for effective immunotherapy in relapsing multiple sclerosis. E Bio Medicine. 2017; 16: 41-50.

31. Bose T. Role of immunological memory cells as a therapeutic target in multiple sclerosis. Brain Sci. 2017; 7 (11): E148.

32. Ciron J, Audoin B, Bourre B, Brassat D, Durand-Dubief F, Laplaud D, et al. NOMADMUS group, under the aegis of OFSEP, SFSEP. Recommendations for the use of Rituximab in neuromyelitis optica spectrum disorders Rev Neurol (Paris). 2018; 174 (4): 255-64.

33. Kim SH, Kim W, Li XF, Jung IJ, Kim HJ. Repeated treatment with rituximab based on the assessment of peripheral circulating memory $B$ cells in patients with relapsing neuromyelitis optica over 2 years. Arch Neurol. 2011; 68, 1412-20.

34. Kim SH, Jeong $\mathrm{H}$, Hyun JW, Joung $\mathrm{A}$, Jo HJ, Hwang $\mathrm{SH}$, et al. Treatment outcomes with rituximab in 100 patients with neuromyelitis optica: influence of FCGR3A polymorphisms on the therapeutic response to rituximab. JAMA Neurol. 72: 989-95.

35. Kim SH, Huh SY, LeeSJ, Joung A, Kim HJ. A5-yearfollow-up ofrituximab treatment in patients with neuromyelitis optica spectrum disorder. JAMA Neurol. 2013; 70: 1110-7.

36. Thompson SA, Jones JL, Cox AL, et al. B-cell reconstitution and BAFF after alemtuzumab (CAMPATH-1H) treatment of multiple 
sclerosis. J Clin Immunol. 2010; 30: 99-105.

37. Duddy M, Niino M, Adatia F, et al. Distincteffectorcytokineprofi esofmemoryand naive human B cell subsets and implication in multiple sclerosis. J Immunol. 2007; 178: 6092-9.

38. Giovannoni G, Cohen JA, Coles AJ, Hartung HP, Havrdova E, Selmaj KW, et al. CARE-MS II Investigators. Alemtuzumab improves preexisting disability in active relapsing-remitting MS patients. Neurology. 2016 Nov 8; 87 (19): 1985-92.

39. Van Oosten BW, Lai M, Hodgkinson S, et al. Treatmentofmultiple sclerosiswith the monoclonal anti-CD4 antibody cM-T412:results of a randomized, double-blind, placebo-controlled, MR-monitored phase II trial. Neurology. 1997; 49: 351-7.

40. Ceronie B, Jacobs BM, Baker D, Dubuisson N, Mao Z, Ammoscato $F$, et al. Cladribine treatment of multiple sclerosis is associated with depletion of memory B cells. J Neurol. 2018 May; 265 (5): 1199-209.

41. Giovannoni G, Cohen JA, Coles AJ, Hartung HP, Havrdova E, Selmaj KW, et al. CARE-MS II Investigators. Alemtuzumab improves preexisting disability in active relapsing-remitting MS patients. Neurology. 2016 Nov 8; 87 (19): 1985-92.

42. Havrdova E, Arnold DL, Cohen JA, Hartung HP, Fox EJ, Giovannoni G, et al. CARE-MS I and CAMMS03409 Investigators. Alemtuzumab CARE-MS I 5-year follow-up: Durable efficacy in the absence of continuous MS therapy. Neurology. 2017 Sep 12; 89 (11): 1107-16. Neurology. 2018 Apr 17; 90 (16): 755.

43. Genovese MC, Kaine JL, Lowenstein MB, et al. Ocrelizumab, a humanized antiCD20 monoclonalantibody, inthe treatment of patients with rheumatoidarthritis: a phase I/II randomized, blinded, placebo-controlled, dose-ranging study. Arthritis Rheum 2008; 58: 2652-61.

44. Kuerten S, Jackson LJ, Kaye J, Vollmer TL. Impact of glatiramer acetate on B cell-mediated pathogenesis of multiple sclerosis. CNS Drugs. 2018; 32 (11): 1039-51.

45. Begum-Haque S, Christy M, Ochoa-Reparaz J, Nowak EC, Mielcarz D, Haque A, et al. Augmentation of regulatory B cell activity in experimental allergic encephalomyelitis by glatiramer acetate. J Neuroimmunol. 2011 Mar; 232 (0): 136-44.

46. Ireland SJ, Guzman AA, O Brien DE, Hughes S, Greenberg B,
Flores A, et al. The effect of glatiramer acetate therapy on functional properties of $B$ cells from patients with relapsing-remitting multiple sclerosis. JAMA Neurol. 2014 Nov; 71 (11): 1421-8.

47. Schubert RD, Hu Y, Kumar G, Szeto S, Abraham P, Winderl J, et al. Interferon- $\beta$ treatment requires $B$ cells for efficacy in neuroautoimmunity. J Immunol. 2015 Mar 1; 194 (5): 2110-6.

48. Ramgolam VS, Sha Y, Marcus KL, Choudhary N, Troiani L, Chopra $\mathrm{M}$, et al. B cells as a therapeutic target for IFN- $\beta$ in relapsingremitting multiple sclerosis. J Immunol. 2011; 186 (7): 4518-26.

49. Sabatino JJ, Zamvil SS, Hauser SL. B-cell therapies in multiple sclerosis. Cold Spring Harb Perspect Med. 2019 Feb; 9 (2): a032037.

50. Lehmann-Horn K, Kinzel S, Weber MS. Deciphering the role of B cells in multiple sclerosis-towards specific targeting of pathogenic function. Int J Mol Sci. 2017 Oct; 18 (10): 2048.

51. Gregson A, Thompson K, Tsirka SE, Selwood DL. Emerging small-molecule treatments for multiple sclerosis: focus on B cells. F1000Res. 2019; 8: F1000 Faculty Rev-245.

52. Braley TJ, Segal BM. B-cell targeting agents in the treatment of multiple sclerosis. Curr Treat Options Neurol. 2013 Jun; 15 (3): 259-69.

53. Traub JW, Häusser-Kinzel S, Weber MS. Differential effects of MS therapeutics on B cells-implications for their use and failure in AQP4-positive NMOSD patients. Int J Mol Sci. 2020 Jul; 21 (14): 5021.

54. Claes N, Fraussen J, Stinissen P, Hupperts R, Somers V. B cells are multifunctional players in multiple sclerosis pathogenesis: insights from therapeutic interventions. Front Immunol. 2015; 6: 642.

55. Traub JW, Pellkofer HL, Grondey K, Seeger I, Rowold C, Brück W, et al. Natalizumab promotes activation and pro-inflammatory differentiation of peripheral B cells in multiple sclerosis patients. $J$ Neuroinflammation. 2019; 16: 228.

56. Häusler D, Häusser-Kinzel S, Feldmann L, Torke S, Lepennetier $\mathrm{G}$, Bernard CCA, et al. Functional characterization of reappearing $B$ cells after anti-CD20 treatment of CNS autoimmune disease. Proc Natl Acad Sci USA. 2018 Sep 25; 115 (39): 9773-8.

57. Fernández-Velasco Jl, Kuhle J, Monreal E, et al. Effect of ocrelizumab in blood leukocytes of patients with primary progressive MS. Neurol Neuroimmunol Neuroinflamm. 2021 Mar; 8 (2): e940. 